\title{
Verification of an emerging LCA design tool through real life performance monitoring
}

\author{
Christine Eon ${ }^{1,}$, Luke Murphy ${ }^{2}$, Josh Byrne ${ }^{1}$, and Martin Anda ${ }^{2}$ \\ ${ }^{1}$ Curtin University Sustainability Policy Institute, Curtin University, Perth, Australia \\ 2 School of Engineering and Information Technology, Murdoch University, Perth, Australia
}

Received: 27 February 2017 / Received in final form: 6 July 2017 / Accepted: 27 July 2017

\begin{abstract}
Recent research has demonstrated that low-emission houses often underperform, consuming more energy than predicted by their designs. Life cycle assessments (LCA) have been employed to complement mandatory energy assessments, as they offer a more comprehensive evaluation of greenhouse gas (GHG) emissions over the building lifespan. This research monitored ten energy efficient Australian houses and recorded data about energy use and photovoltaic generation over 1 year. The houses were assessed with a relatively new LCA tool in addition to the Australian mandatory house energy assessment Nationwide House Energy Rating Scheme (NatHERS). The objective of this study was twofold: first, to evaluate the results of the assessment tools compared to actual house energy requirements and second, to understand how design, renewable energy, and occupancy can impact the overall GHG emissions of the houses. The results show that energy use is positively related to NatHERS ratings, but some of the high performance houses perform poorly and there was significant variation in energy use between houses with the same ratings. The LCA revealed that modern houses have higher embodied energy than older houses, while solar panels are not always used to their full potential. This paper attributes some of the variations between theoretical and actual energy use to construction issues and occupant practices.
\end{abstract}

\section{Introduction}

Recent research has shown that low energy buildings may not perform as intended due to barriers related to the inaccuracy of energy assessments [1], poor construction and verification processes $[2,3]$ and occupant behaviour [4,5]. These issues have raised concerns about the reliability of energy assessments and their sufficiency to effectively reduce greenhouse gas (GHG) emissions in the building sector. Current building regulations have also been criticized due to their narrow scope and focus on operational energy alone [6]. The mandatory Australian residential energy assessment (Nationwide House Energy Rating Scheme - NatHERS) is even more limited, as it is restricted to reducing the energy demand for space heating and cooling. These are the largest energy consumers in residential dwellings, representing $40 \%$ of the total energy use, but the contribution of water heating and appliances, for instance, is also high and cannot be neglected [7]. Compliance inspections during the construction phase are also not mandated by NatHERS and poor construction practices, in particular related to the installation of insulation, have resulted in buildings that divert from their original accredited design $[3,8,9]$.

\footnotetext{
* e-mail: christine.eon@curtin.edu.au
}

As countries strive to achieve low energy buildings, the contribution of embodied energy in materials becomes more important in relative terms [10,11]. Over the last decades the number of people per household has declined while the number of households has increased [12], creating a higher demand of resources per capita and increasing the carbon footprint due to additional appliances and infrastructure. This problem is more accentuated in low density countries such as Australia, where houses are also becoming larger [13]. Life cycle assessments (LCA) are increasingly being deployed to complement mandatory energy assessments, as they offer a more comprehensive evaluation of GHG emissions over the whole building lifespan. LCAs are still voluntary, but they are now part of leading international building sustainability assessments, such as BREEAM, LEED and Green Star. Despite the comprehensive nature of LCAs, few studies have verified actual energy use compared to LCA predictions.

This research evaluates the energy performance and carbon footprint of ten Australian single detached houses considered to be above standards from a national regulation point of view. These houses were assessed with the LCA software eToolLCD in addition to the compulsory energy efficiency assessment mandated by the Australian National Construction Code (NCC). The ten studied houses have had their energy use and photovoltaic (PV) 
Table 1. Monitoring equipment installed in the ten houses.

\begin{tabular}{lll}
\hline Parameters monitored & Meters and sensors & Data logger \\
\hline Gas & Ampy 750 \& pulse kit for 750 meter & \\
Grid electricity & Schneider Electric iEM3110 & Schneider Electric COM'X 200 \\
Photovoltaic generation & Latronics kWh & \\
\hline
\end{tabular}

generation monitored for 1 year while occupied, enabling the comparison between predicted and actual house performance from the perspective of the two distinct rating tools (NatHERS and eToolLCD). House inspections and interviews with house occupants allowed us to obtain a complete picture of the impacts that design, renewable energy, and occupancy have on the overall GHG emissions of the houses.

\section{Methodology}

\subsection{Profile of the ten houses}

The houses selected for this research are located in the City of Fremantle, in Western Australia. The houses have mixed occupancy and designs (Appendix A), however, they all possess technologies or design components that make them more energy efficient than the average Australian home. Four of the houses have been built to meet the Australian building code requirements, which oblige all homes built since 2012 to achieve a rating of at least 6-Star NatHERS. ${ }^{1}$ One house is classified as deemed-to-satisfy (DTS), that is, it has not been rated, but it follows prescribed designs specified by the NCC. Three houses are considered to be high performance homes, that is, their rating is above 7 Star. And finally, two houses are older homes which have been retrofitted to include insulation, PV systems and solar hot water. Nine of the houses possess a PV system and eight possess a solar hot water system.

\subsection{Quantitative data collection}

Monitoring equipment (Tab. 1) was installed in the ten participant houses in order to measure total grid electricity use, gas consumption and photovoltaic electricity generation in the houses that possess solar panels. The monitoring equipment consists of multiple sensors that are coupled to existing meters and transmit electric pulses to a data logger. The data logger collects the data at $15 \mathrm{~min}$ intervals and transmits csv files to the researchers remotely through a $2 \mathrm{G}$ wireless internet connection.

\subsection{Life cycle assessment}

The eToolLCD software was used to determine the energy and carbon emissions associated with the houses during their whole lifespan. Whilst software such as Envest,

\footnotetext{
${ }^{1}$ Rating scores are given on a scale of $0-10$, with the higher the star rating, the less the energy per square meter required to make a house thermally comfortable. Theoretically a 10-Star house should require very little or no artificial heating or cooling to be comfortable year round.
}

LCADesign, Gabi, and Simapro, for instance, are more internationally renowned than eToolLCD, the latter was chosen for this study as it was developed in Australia and is tailored to the local market, taking the local building construction practices into consideration. The LCA accounts for processes involved during material manufacture, transportation, assembly, maintenance, house operation, demolition and disposal. The embodied energy is calculated according to the design entered in the software by the user and modelled based on existing international LCA databases as well as local industry practices [14]. The software also considers renewable energy, fixtures, appliances and water use.

The lifespan of each home was estimated by the software based on the design quality of the building, the ownership type, the local density, the house typology (i.e. strata complex, single detached house, apartment) and the suburb redevelopment potential. Houses B, C, D and J are heritage listed which implies that their facades must be preserved; however, they all have undergone a major recent renovation and their lifespans were based on these.

Two scenarios were simulated for each house. Scenario 1 predicted energy use and embodied energy per year, calculating a predicted carbon footprint based on the average Australian household energy use and appliances, building area and NatHERS rating. For this purpose, the retrofitted and DTS houses were assumed to be the equivalent of a 6-Star NatHERS rating. Scenario 2 used inputs from real data monitoring to determine total yearly energy use. The embodied energy determined in Scenario 1 was adjusted in Scenario 2 to take the household appliances into consideration, rather than averages.

House design information was obtained through plans supplied by the house owners. House visits were also undertaken at the start of the project to collect appliance information and any other missing data not included in the plans. Missing specifications that could not be verified onsite were assumed based on industry common practices (Appendix B).

\subsection{House inspections}

At the end of 12 months of data collection house inspections were conducted to identify possible missing insulation and air infiltrations. A thermal imaging camera Testo 870 was employed for verification of the insulation in walls and ceilings. Other sources of heat gain were also visually detected through thermography [3].

Previous research has shown that occupant behaviour is often a cause of discrepancy between theoretical and actual energy use in the home, differences varying up to $37 \%$ [5]. Whilst occupant behaviour is not the focus of this research, semi-structured interviews were conducted at the end of 


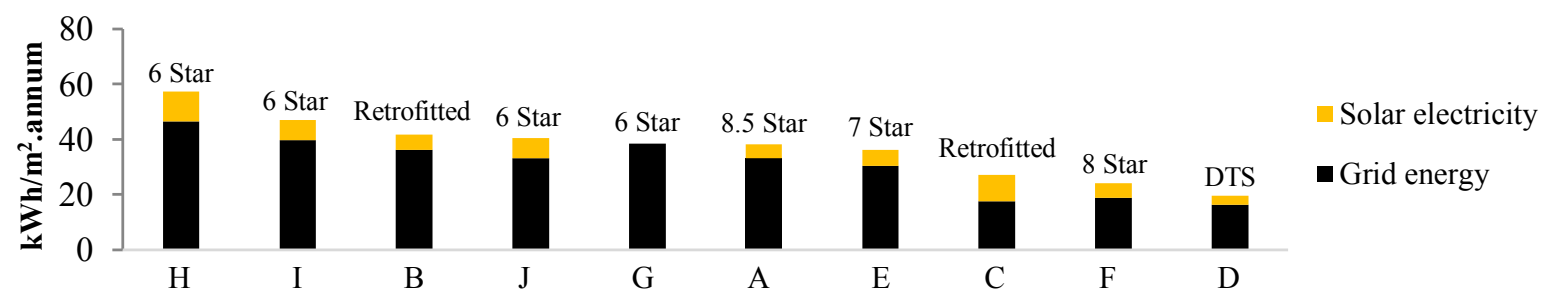

Fig. 1. Total energy use per square meter in the ten participant homes in 2015.

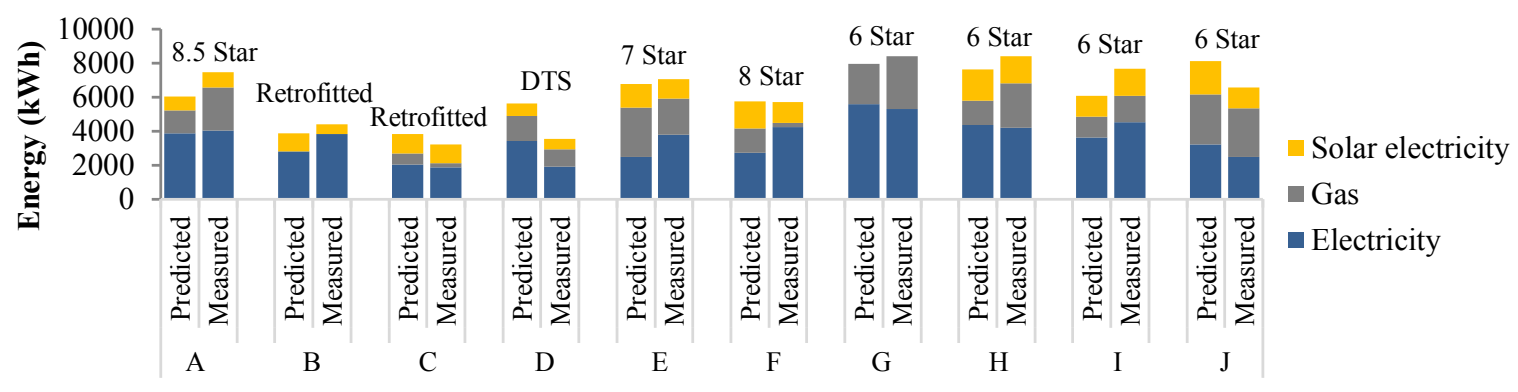

Fig. 2. Total energy prediction per year using eToolLCD compared to the total measured operational energy used in participant households during 2015 .

the monitoring period to identify whether occupant practices could be affecting the LCA and NatHERS predictions.

\section{Results}

\subsection{NatHERS}

Mechanical heating and cooling are typically the highest energy consumers in Australian houses, responsible for $40 \%$ of the total energy use [7]. Hence, it is expected that higher NatHERS Star-rated houses, which in theory require less heating and cooling loads per square meter, consume less energy per area than lower NatHERS Star-rated houses. Figure 1 shows the total energy use per square meter in each of the participant houses. Results show that in general, the higher the Star rating, the lower the energy consumption per square meter. However, some surprising results were found: the 8.5-Star house used significantly more energy than the 8-Star house, the 7-Star house, the retrofitted House C and the DTS house. There is also a 33\% variance between the total energy consumption of 6-Star houses with similar designs.

\section{2 eToolLCD}

\subsubsection{Operational energy use}

The eToolLCD operational energy estimates are based mostly on the heating and cooling loads required throughout the year. However, additional elements such as lighting, hot water systems and appliances are also factored into the equation. Figure 2 shows the results of the total energy prediction per year (Scenario 1) compared to the total measured operational energy used (Scenario 2) in participant households during 2015. Differences between predicted and measured energy use ranged between $1 \%$ (House F) and $58 \%$ (House D), the average variation being $17 \%$.

\subsubsection{Carbon footprint \\ 3.2.2.1 Embodied carbon emissions}

The embodied carbon of the ten houses include emissions generated from material production, transportation, construction, maintenance (recurring), building demolition and debris disposal. Recurring emissions are closely related to the buildings lifespans, which were estimated as 40 years for all the houses except for House E, which was estimated to have a lifespan of 80 years. This difference is due to House E being the only house that is part of a strata complex, sharing walls with two other dwellings. Additionally, this house was architecturally designed, allowing for flexible use of space. The other houses are all located on larger individual blocks with single ownership and lower density.

Figure 3 shows the total embodied energy as well as the embodied energy per square meter of the ten houses averaged per year. Emissions generated from material production account for $41 \%$ of the total building embodied carbon, followed by recurring maintenance over the building life cycle $(26 \%)$, demolition and disposal (17\%), transportation (13\%) and construction (3\%) (Fig. 3). The building structure is the main contributor to embodied carbon [15]. Accordingly, the floor area and the choice of structural materials are influential factors driving the overall building embodied emissions. House $\mathrm{C}$ has the highest embodied carbon per square meter out of the ten houses (Fig. 3), mostly due to the use of limestone (17\%) for the construction of walls. Other houses presenting high embodied carbon per square meter include modern houses built within the last 10 years (Houses H, I, A, G and F). These houses' structures are mostly made of brick, concrete and steel, which possess high embodied carbon, producing, respectively, $13 \%, 12 \%$ and $9 \%$ of the total house embodied emissions. On the other hand, three out of the four houses possessing the lowest embodied carbon per square meter 


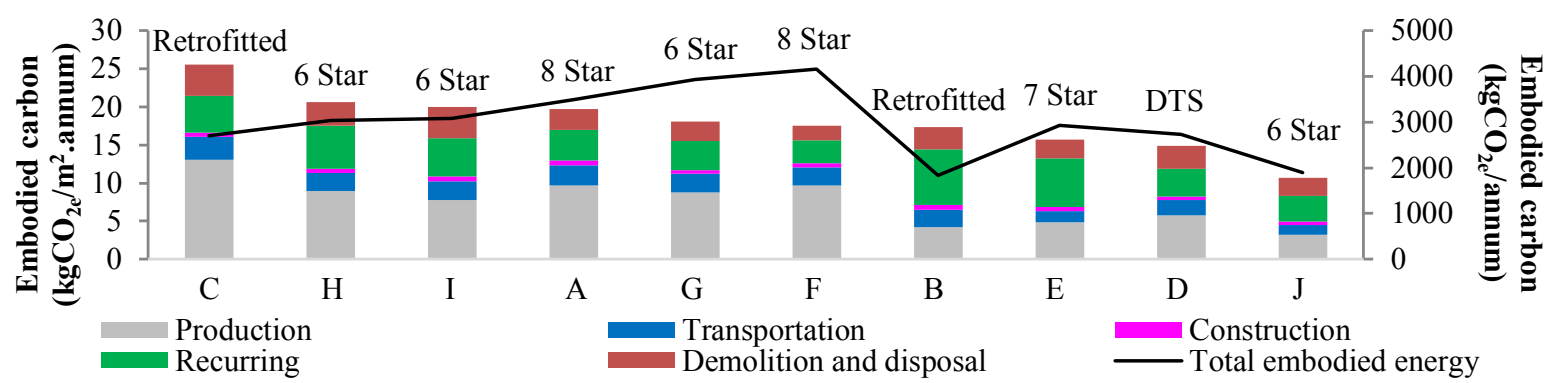

Fig. 3. Yearly embodied carbon per square meter categorised into the five building life cycle stages and total yearly embodied energy for each house.

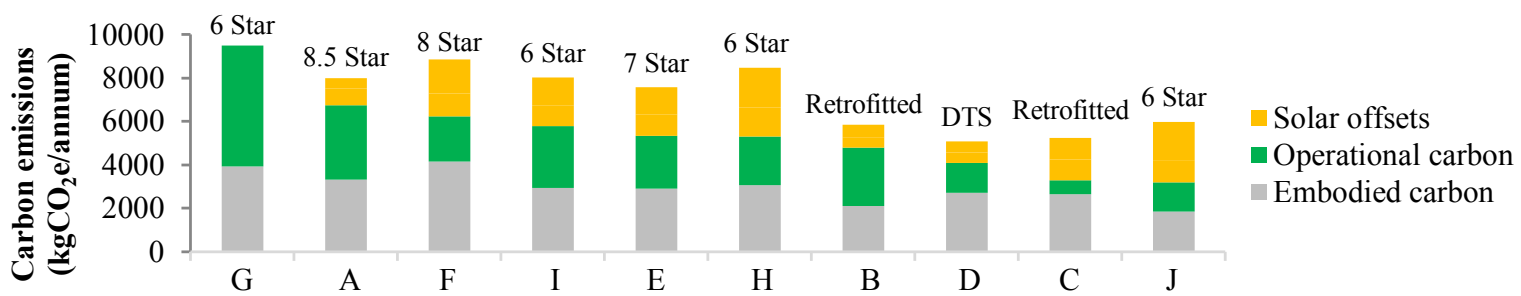

Fig. 4. Yearly carbon footprint and solar offsets.

(Houses B, D and J) were built in the first half of the 1900s and their structure is mainly timber. These houses generate relatively low $(31 \%)$ carbon emissions during the material production stage and the highest percentages of emissions are related to maintenance. Despite the high proportions of concrete and steel in its structure, House E presents a low yearly embodied carbon per area due to its high lifespan. Embodied emissions in this house are mostly due to maintenance, including the use of refrigerants and replacement of solar panels, causing, respectively, 15\% and $7 \%$ of yearly embodied carbon emissions.

For the total yearly embodied carbon of each house, the houses with the highest embodied energy are all modern 6 8.5-Star houses (F, G, A, I, H) (Fig. 3). Not only were they built with high embodied carbon materials, but they also have large floor plans in comparison to older houses in the same region and similar socio-economics. The average area of new homes (built after 2006) in this sample is $186 \mathrm{~m}^{2}$, while old houses average $130 \mathrm{~m}^{2}$. House F (8 Star), for instance, has $238 \mathrm{~m}^{2}$ of habitable area in addition to a brick double garage, a brick fence and cement driveways. In contrast, House B's habitable area is $106 \mathrm{~m}^{2}$ and the house structure is timber. Its total yearly embodied carbon emissions are 2.3 times less than House F.

\subsubsection{Total carbon emissions}

Solar panels offset on average $51 \%$ of the houses yearly operational carbon emissions (Fig. 4). Without these offsets, operational emissions would represent $58 \%$ of the total emissions over the building lifetime. However, renewable energy reduces this proportion to $41 \%$ and building materials become the main contributor to GHG emissions. As a result, modern houses have higher total carbon footprints as compared to older homes due to larger floor plans and structural materials, as previously discussed.
It has been shown, however, that $51.8 \%$ of PV systems in Australia do not perform to capacity [16]. This research has found that four of the houses possessing PV systems do not operate optimally. House J's system, for instance, was installed on a South facing roof and according to the eTool model, it is generating $6 \%$ less electricity than predicted. House D's PV system is shaded by a neighbouring tree, generating $\mathbf{1 5 . 7 \%}$ less electricity than expected. Finally, the PV system on House B is generating $34.6 \%$ less electricity than expected. This is likely due to dust accumulated on the panels surface, as the owners revealed that the panels had never been cleaned. Monitoring data also revealed that the PV circuit breaker of House F tripped after wet weather events and stopped generating electricity for 3 weeks as the failure was not immediately detected by the house occupants.

\subsection{House inspections}

Thermography revealed that all the houses presented insulation gaps in the ceiling and walls mostly around the corners (Fig. 5a). Missing insulation was also commonly found above attic hatch doors and around downlights (Fig. 5b). The efficiency of water heaters in some cases was compromised due to the lack of insulation around outlet pipes (Fig. 5c). The inspections also revealed that some houses did not possess shading devices on West and East facing windows, becoming very hot in summer. These design flaws could be affecting the operational component of the LCA results.

Occupant practices were also considered as a potential contributor to the variations found between predicted and actual energy use. Whilst these behaviours and practices were not explored in depth in this study, they could explain, for instance, the difference of $1200 \mathrm{kWh}$ between predicted and measured grid electricity for House D (Fig. 2). Interviews 
(a)

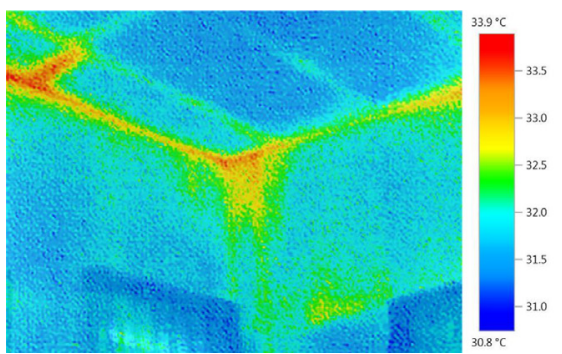

(b)

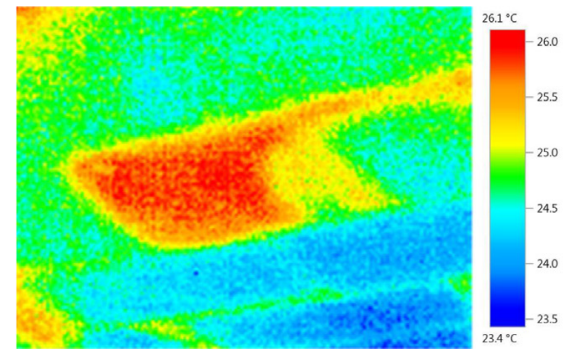

(c)

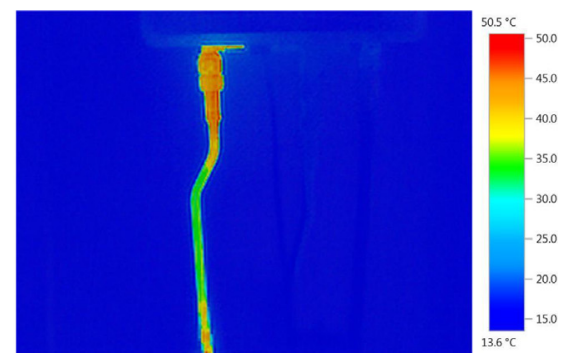

Fig. 5. Thermal images of (a) ceiling corners; (b) down lights and (c) hot water system outlet pipe.

with the house occupants revealed that while they possess a reverse cycle air conditioner unit, they prefer to use a fireplace to heat the house in winter and they rarely use the cooling system in summer. House $\mathrm{H}$, on the other hand, uses significantly more gas than expected (Fig. 2). According to the house owner, her children enjoy having long showers. Unexpected behaviours are not considered by either NatHERS or eToolLCD but can significantly affect the results and should be further explored.

\section{Conclusion}

Ten houses were monitored over 1 year and energy use was compared with NatHERS and LCA estimates. While high performance houses used less energy per square meter than 6Star houses, there was significant energy variation between houses with the same rating. eToolLCD predictions also differed up to $58 \%$ from actual energy use. Reasons for these variations included issues associated with construction and maintenance. Insulation gaps were found in all houses and are believed to be impacting on thermal comfort. It was also revealed that PV systems are underperforming due to wrong placement, lack of maintenance and system failure. Interviews with households also revealed that occupant practices vary considerably between houses, ultimately affecting dwelling performance. As houses become more energy efficient, the contribution of embodied energy becomes higher as a proportion of total life cycle emissions. This study shows that embodied energy contributes $59 \%$ of total emissions in houses that possess renewable energy. It was also revealed that the modern houses in this study generate higher life cycle emissions compared to older houses due to the use of high embodied energy materials in their construction as well as possessing larger floor plans. While current policies target the reduction of residential GHG emissions through energy efficiency measures, this research shows that embodied energy should be addressed. Moreover, maintenance, PV performance monitoring and occupant awareness should also be considered. It is recommended that further research is conducted to offer a better understanding about patterns of occupant practices and their relationship to energy use at a home level.

\section{Implications and influences}

The research findings have implications for policy makers who currently focus on reducing residential greenhouse gas emissions through simulations of operational energy use.
The findings from this research show that a more holistic approach needs to be taken, considering all stages of the building lifecycle.

This research is funded by the CRC for Low Carbon Living Ltd. and supported by the Cooperative Research Centre program, an Australian Government initiative.

\section{References}

1. R. Lowe, T. Oreszczyn, Regulatory standards and barriers to improved performance for housing, Energy Policy 36, 4475 (2008)

2. IEA, Energy efficiency requirements in building codes, energy efficiency policies for new buildings (International Energy Agency, 2008)

3. DSD, New home energy efficiency compliance inspections, National Energy Efficient Buildings Project - Phase 2, S. A. D. o. S. Development, 2015

4. O. Guerra Santin, L. Itard, H. Visscher, The effect of occupancy and building characteristics on energy use for space and water heating in Dutch residential stock, Energy Build. 41, 1223 (2009)

5. Z.M. Gill, M.J. Tierney, I.M. Pegg, N. Allan, Low-energy dwellings: the contribution of behaviours to actual performance, Build. Res. Inform. 38, 491 (2010)

6. T. Moore, J. Morrissey, R.E. Horne, Future policy directions for zero emission housing in Australia: implications from an international review and comparison, in Presented at the State of Australia Cities National Conference, Melbourne, Australia, 2011

7. DEWHA, Energy use in the Australian Residential Sector 1986-2020 (Department of the Environment, Water, Heritage and the Arts, 2008)

8. DSD, National energy efficient building project, Department of State Development - Government of South Australia, 2014

9. M. Ambrose, M. Syme, House energy efficiency inspections project - final report, Department of Industry, Innovation and Science, 2015

10. E. Himpe, L. Trappers, W. Debacker, M. Delghust, J. Laverge, A. Janssens et al., Life cycle energy analysis of a zero-energy house, Build. Res. Inform. 41, 435 (2013)

11. A. McManus, M.R. Gaterell, L.E. Coates, The potential of the Code for Sustainable Homes to deliver genuine 'sustainable energy' in the UK social housing sector, Energy Policy 38, 2013 (2010) 
12. Z. Ren, Z. Chen, X. Wang, Climate change adaptation pathways for Australian residential buildings, Build. Environ. 46, 2398 (2011)

13. T. Moore, S. Clune, J. Morrissey, The importance of house size in the pursuit of low carbon housing, in Presented at the State of Australian Cities, Sydney, Australia, 2013

14. R. Haynes, Embodied energy calculations within life cycle analysis of residential buildings, 2010, 24 April 2016, available: http://www.etoolglobal.com/wp-content/uploads/2012/10/ Embodied-Energy-Paper-Richard-Haynes.pdf
15. S. Li, H. Yan, J. Chen, L. Shen, A life cycle analysis approach for embodied carbon for a residential building, in Proceedings of the 20th International Symposium on Advancement of Construction Management and Real Estate, edited by Y. Wu, S. Zheng, J. Luo, W. Wang, Z. Mo, L. Shan (Springer Singapore, Singapore, 2017), pp. 1185-1196

16. S. Jarnason, J. Copper, A. Sproul, Intelligent automated monitoring of commercial photovoltaic (PV) systems - final CRC report, Low Carbon Living CRC, 2014

\section{Appendices}

Appendix A. Dwelling characteristics and occupancy.

\begin{tabular}{|c|c|c|c|c|c|c|}
\hline House & $\begin{array}{l}\text { Year } \\
\text { built }\end{array}$ & Typology & $\begin{array}{l}\text { Floor } \\
\text { area }\left(\mathrm{m}^{2}\right)\end{array}$ & Design & Technologies & $\begin{array}{l}\text { NatHERS/ } \\
\text { description }\end{array}$ \\
\hline A & 2009 & $\begin{array}{l}\text { Detached } \\
\text { house }\end{array}$ & 177 & $\begin{array}{l}\text { Double brick walls; concrete } \\
\text { slab; R3 ceiling insulation; R1.5 } \\
\text { roof insulation; North orientation. }\end{array}$ & $\begin{array}{l}1.2 \mathrm{~kW} \text { PV system; } \\
\text { solar hot water } \\
\text { with gas booster }\end{array}$ & 8.5 Star \\
\hline B & 1950 & $\begin{array}{l}\text { Detached } \\
\text { house }\end{array}$ & 106 & $\begin{array}{l}\text { Timber frame walls with R2 } \\
\text { insulation; R } 2.5 \text { ceiling insulation; } \\
\text { suspended timber floor with R } 1.5 \\
\text { insulation; North orientation. }\end{array}$ & $\begin{array}{l}1.5 \mathrm{~kW} \text { PV system; } \\
\text { solar hot water with } \\
\text { electricity booster }\end{array}$ & Retrofitted \\
\hline $\mathrm{C}$ & 1899 & $\begin{array}{l}\text { Detached } \\
\text { house }\end{array}$ & 106 & $\begin{array}{l}\text { Limestone and double brick walls; } \\
\text { suspended timber floor and concrete } \\
\text { slab; R3.5 ceiling insulation; R1.5 } \\
\text { roof insulation; South-East orientation. }\end{array}$ & $\begin{array}{l}1.68 \mathrm{~kW} \text { PV system; } \\
\text { solar hot water with } \\
\text { electric booster }\end{array}$ & Retrofitted \\
\hline $\mathrm{D}$ & 1920 & $\begin{array}{l}\text { Detached } \\
\text { house }\end{array}$ & 183 & $\begin{array}{l}\text { Double brick and timber frame walls } \\
\text { with R3.5 insulation; concrete and } \\
\text { suspended timber floor; R3 ceiling } \\
\text { insulation; R1.5 roof insulation; } \\
\text { North orientation. }\end{array}$ & $\begin{array}{l}1.1 \mathrm{~kW} \text { PV system; } \\
\text { solar hot water with } \\
\text { gas booster }\end{array}$ & $\begin{array}{l}\text { Deemed- } \\
\text { to-satisfy }\end{array}$ \\
\hline $\mathrm{E}$ & 2011 & $\begin{array}{l}\text { Strata } \\
\text { complex }\end{array}$ & 186 & $\begin{array}{l}\text { Rammed earth and insulated panel } \\
\text { walls with R2.5 insulation; concrete } \\
\text { slab; R3 ceiling insulation; R } 2.5 \text { ceiling } \\
\text { insulation; North orientation. }\end{array}$ & $\begin{array}{l}2 \mathrm{~kW} \text { PV system; } \\
\text { instantaneous gas } \\
\text { water heater }\end{array}$ & 7 Star \\
\hline $\mathrm{F}$ & 2011 & $\begin{array}{l}\text { Detached } \\
\text { house }\end{array}$ & 238 & $\begin{array}{l}\text { Rammed earth and double brick walls } \\
\text { with R2.5 insulation; concrete slab; } \\
\text { R3 ceiling insulation; R2.5 roof } \\
\text { insulation; North orientation. }\end{array}$ & $\begin{array}{l}2.28 \mathrm{~kW} \text { PV system; } \\
\text { solar hot water with } \\
\text { electric booster }\end{array}$ & 8 Star \\
\hline $\mathrm{G}$ & 2013 & $\begin{array}{l}\text { Detached } \\
\text { house }\end{array}$ & 218 & $\begin{array}{l}\text { Double brick walls; concrete slab; } \\
\text { R4 ceiling insulation; West orientation. }\end{array}$ & $\begin{array}{l}\text { Solar hot water; } \\
\text { with electric booster }\end{array}$ & 6 Star \\
\hline
\end{tabular}


Appendix B. Major missing specification assumptions for the LCA modelling.

\begin{tabular}{|c|c|c|}
\hline Component & Assumption & Justification \\
\hline $\begin{array}{l}\text { Material quantity for the } \\
\text { roof structure }\end{array}$ & $\begin{array}{l}\text { An eToolLCD template for the roof } \\
\text { structure was used. It calculates the } \\
\text { material quantity based on the roof } \\
\text { area and pitch. }\end{array}$ & $\begin{array}{l}\text { The template is based on common } \\
\text { construction practices. }\end{array}$ \\
\hline Ceiling insulation & $\begin{array}{l}\text { For houses with ceiling insulation } \\
\text { but no specification, an } \\
R \text {-value of } 2.5 \text { was assumed. }\end{array}$ & $\begin{array}{l}\text { This is a common } R \text {-value used in } \\
\text { the ceiling. }\end{array}$ \\
\hline $\begin{array}{l}\text { Construction materials in } \\
\text { the heritage part of House } \mathrm{C}\end{array}$ & $\begin{array}{l}\text { Limestone walls and suspended } \\
\text { timber floors. }\end{array}$ & $\begin{array}{l}\text { These were common building } \\
\text { materials used in the early 1900s } \\
\text { in the City of Fremantle. }\end{array}$ \\
\hline Staircases & $\begin{array}{l}\text { An eToolLCD template for timber } \\
\text { staircases was used. }\end{array}$ & $\begin{array}{l}\text { The template is based on common } \\
\text { construction practices. }\end{array}$ \\
\hline Suspended floor structure & $\begin{array}{l}\text { An eToolLCD template for elevated } \\
\text { wooden stilts was used } \\
\text { when specific details about the underfloor } \\
\text { structure were not available. }\end{array}$ & $\begin{array}{l}\text { The template is based on common } \\
\text { construction practices. }\end{array}$ \\
\hline $\begin{array}{l}\text { Ducted air conditioner } \\
\text { duct length }\end{array}$ & $\begin{array}{l}\text { An eToolLCD template for duct air } \\
\text { conditioner was used. } \\
\text { The length of the duct was estimated based } \\
\text { on the house habitable area. }\end{array}$ & $\begin{array}{l}\text { The template is based on common } \\
\text { construction practices. }\end{array}$ \\
\hline Tiled areas & $\begin{array}{l}\text { The tiled area of bathrooms, kitchens and } \\
\text { laundries was estimated. }\end{array}$ & $\begin{array}{l}0.5 \mathrm{~mm} \text { thick tiles have a relatively } \\
\text { small embodied energy compared to } \\
\text { a brick wall. This estimation does not } \\
\text { have a significant impact in the overall } \\
\text { embodied energy of the house. }\end{array}$ \\
\hline
\end{tabular}

Cite this article as: Christine Eon, Luke Murphy, Josh Byrne, Martin Anda, Verification of an emerging LCA design tool through real life performance monitoring, Renew. Energy Environ. Sustain. 2, 26 (2017) 